\title{
Characterization and Batch Anaerobic Digestion Study of Banana Wastes
}

\author{
R. Divyabharathi", R. Angeeswaran, K. Jagadeeshkumar and S. Pugalendhi \\ Department of Bioenergy, AEC\&RI, Tamil Nadu Agricultural University, \\ Coimbatore - 641003, Tamil Nadu, India \\ *Corresponding author
}

\begin{tabular}{|c|c|}
\hline & A B S T R A C T \\
\hline & \multirow{6}{*}{$\begin{array}{l}\text { Agro industries like banana processing industries result in large amount of waste } \\
\text { generation and they are usually dumped causing serious environmental pollution. Since } \\
\text { banana wastes are putrid organic wastes, they are ideal for anaerobic digestion. Hence } \\
\text { utilizing these wastes for biogas production is a sustainable way of deriving energy from } \\
\text { waste so that the two major concerns, energy demand and environmental protection is } \\
\text { achieved. The paper describes the analysis of the physico-chemical characteristics of } \\
\text { banana wastes viz. banana peel, pseudo stem and fruit bunch stem. Also the banana wastes } \\
\text { were tested for its biogas production potential through batch anaerobic digestion } \\
\text { experimental setup. The characterization study showed the major biomethanation } \\
\text { characteristics, total solids and volatile solids concentration in banana wastes to be in the } \\
\text { range of } 14 \text { to } 19 \% \text { and } 10.1 \text { to } 14.63 \% \text { respectively. From batch study, the specific biogas } \\
\text { production }(l / \mathrm{kg} \text { of feed) was found to be around } 0.35 \mathrm{l} / \mathrm{kg} / \text { day and also the combination of } \\
75 \% \text { mashed banana peel with } 25 \% \text { cow dung showed best results with higher gas } \\
\text { production of } 3.85 l \text {. The physico-chemical characteristic analysis and the batch digestion } \\
\text { study of banana wastes indicated its potential as an effective feedstock for biogas } \\
\text { production. }\end{array}$} \\
\hline & \\
\hline $\begin{array}{l}\text { Banana wastes, } \\
\text { Characterization, } \\
\text { Anaerobic } \\
\text { digestion, Biogas. }\end{array}$ & \\
\hline Article Info & \\
\hline $\begin{array}{l}\text { Accepted: } \\
\text { 26 June } 2017 \\
\text { Available Online: } \\
\text { 10 July } 2017\end{array}$ & \\
\hline & \\
\hline
\end{tabular}

\section{Introduction}

Biogas can be produced from any biodegradable feedstock that is suitable for anaerobic digestion. Generally the feedstock used for biogas production may be solid, slurries and both concentrated and dilute liquids. The range of potential waste feedstock is much broader including cow dung, municipal wastewater, residual sludge, food waste, food processing wastes, dairy manure, poultry manure, yard wastes, municipal solid wastes, etc. Efforts are being taken in exploring alternate feedstock for biogas production. Banana wastes can also be used as an alternate feedstock as they are a concentrated source of putrid organic waste, ideal for anaerobic digestion to produce a valuable energy source in form of biogas. Channeling these wastes into the production of biogas by anaerobic digestion is also an effective way of waste management.

Banana and plantains are grown in about 120 countries. India leads the world in banana production where it is cultivated in approximately 5 lakh hectares with an annual production of 169 million tones, contributing to $27 \%$ of world's banana production. The varieties grown generally in Tamil Nadu are Virupakshi, Robusta, Red Banana, Poovan, Rasthali, Nendran, Monthan, Karpuravalli, 
Sakkai, Peyan and Matti. (Source: NHB report on Banana). Processing of banana results in a huge amount of waste generation, leaves, stems and peels and to some extent the degraded bananas itself. Indiscriminate disposal of these wastes when decomposed produces noxious gases such as hydrogen sulphide and ammonia, which pose serious environmental hazards. Each hectare of banana crop generates nearly 220 tons of plant residues like leaves, pseudo stem etc. consisting mainly of lignocelluloses material.

In countries like India, where $4.796 \times 10^{5}$ ha of banana is cultivated, farmers generally discard the banana wastes into rivers, lake and on roads or give as feedstock to cattle. Thus turning them into biomass feedstock offers a better waste management option and also source of energy production. Keeping this in view, banana processing wastes like peel, peduncle and pseudo stem are taken as feedstock in the study. They are evaluated for its suitability and potential for biogas generation through the characterization and batch digestion studies.

\section{Materials and Methods}

The banana wastes were collected from Faisal Chips company, Selvapuram, Coimbatore and were characterized for assessing its suitability for biomethanation. Samples taken for the study were banana stem, peel and peduncle of Musa Nendran cultivar (AAB). The banana wastes collected were mashed by using a crusher of $15 \mathrm{hp}$ motor capacity and used for analysis. The samples of banana wastes taken are shown in figure 1 .

\section{Moisture content and total solids}

Moisture content and total solids of the biomass are an important parameter, which affects the biogas production.
Moisture content was determined by drying known weight of sample in an electric oven at $103 \pm 2^{\circ} \mathrm{C}$ up to the arrival of constant weight. The remaining percentage of weight gives the total solids content in the sample (Browning, 1967).

\section{Volatile matter}

The volatile matter was determined using muffle furnace (ASTM D 3175-89). To measure the volatile content, known quantity of dried sample was taken in a closed crucible and kept inside the muffle furnace at $650^{\circ} \mathrm{C}$ for six minutes and again at $750^{\circ} \mathrm{C}$ for another six minutes. The loss in weight of the sample was found out and the percent of volatile matter was calculated as

Volatile Matter, $(\%)=$

$\frac{\text { Loss in weight of the sample, } \mathrm{g}}{\text { Weight of moisture fee sample, } \mathrm{g}} \times 100$

\section{Ash content}

The ash content of the selected biomaterial was found out (ASTM D 3174-89) by taking a known quantity of dried sample in an open crucible and keeping it in a muffle furnace at about $750^{\circ} \mathrm{C}$ up to reaching a standard weight. The ratio between the remaining weight of the materials in the crucible and the sample taken was the fraction of ash content of tested material.

Ash content, $(\%)=$

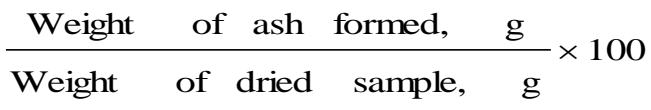

\section{Fixed carbon}

The fixed carbon of samples was calculated by subtracting the sum of ash content (\%) and volatile matter (\%) from 100 . The fixed 
carbon is the content that remains after complete volatilization.

Fixed carbon, $\%=100-($ volatile matter $(\%)$ + ash content $(\%)$ )

\section{pH}

The $\mathrm{pH}$ is the negative logarithm of the hydrogen ion concentration indicating the degree of acidity and alkalinity of the water sample. The $\mathrm{pH}$ of the samples was estimated using the electrometric method (APHA, 1989).

\section{$\mathrm{C}: \mathrm{N}$ ratio}

The concentrations of carbon and nitrogen are an important parameter which determines the performance of the anaerobic digestion process, as one or the other usually constitutes the limiting factor. Whereas carbon constitutes the energy source for the microorganisms, nitrogen serves to enhance microbial growth.

If the amount of nitrogen is limiting, microbial populations will remain small and it will take longer to decompose the available carbon. Excess nitrogen, beyond the microbial requirement, is often lost from the process as ammonia gas.

The $\mathrm{C}$ : $\mathrm{N}$ ratio was found by separately estimating the Total Organic Carbon (TOC) and Total Kjeldhal Nitrogen (TKN).

\section{Estimation of Total Organic Carbon (TOC)}

The TOC was estimated following the wet digestion method of Walkley and Black as described by Nelson and Somners (1996). The diluted $20 \mathrm{ml}$ sample was digested with 50-75 $\mathrm{ml}$ of $1 \mathrm{~N} \mathrm{~K} \mathrm{Kr}_{2} \mathrm{O}_{7}$ with $20 \mathrm{ml}$ of Conc. $\mathrm{H}_{2} \mathrm{SO}_{4}$. After 30 minutes $10 \mathrm{ml}$ of Ortho phosphoric acid was added. This was titrated against $1 \mathrm{~N}$ Ferrous Ammonium Sulphate
(FAS) with diphenylamine as indicator. A blank was also run.

$\operatorname{TOC}(\%)=\frac{(\mathrm{Bv}-\mathrm{Sv}) \times \mathrm{NFAS} \times 100 \times 0.03}{\mathrm{Vs}}$

Where,

$\mathrm{Bv}=$ Blank titre value

$\mathrm{Sv}=$ Sample titre value

NFAS $=$ Normality of FAS

$\mathrm{Vs}=$ Volume of test Sample

\section{Estimation of Total Kjeldhal Nitrogen (TKN)}

Available Nitrogen was estimated in the samples by micro Kjeldahl method. To $1 \mathrm{ml}$ of sample, 2-3 $\mathrm{ml}$ of 25 per cent $\mathrm{KMnO}_{4}$ solution was added followed by few drops of Conc. $\mathrm{H}_{2} \mathrm{SO}_{4}$. To this $10-15 \mathrm{ml}$ of diacid $\left(\mathrm{H}_{2} \mathrm{SO}_{4} \& \mathrm{HClO}_{3}\right.$ in the ratio 5:2) was added and digestion was carried out in a Kjel plus digestion unit. $5 \mathrm{ml}$ each of the digested samples was distilled with 20 to $50 \mathrm{ml}$ of 40 per cent $\mathrm{NaOH}$ and the distillate titrated against $0.05 \mathrm{~N} \mathrm{H}_{2} \mathrm{SO}_{4}$.

Total Kjeldhal

Nitrogen, $\mathrm{mg} / \mathrm{l}=\frac{\text { Titre } \text { value } \times 14 \times \text { Vol. of acid made up }}{\text { Volume of acid pipetted }} \times 100$

\section{Anaerobic digestion of banana wastes}

Anaerobic digestion involves four stages viz. hydrolysis, acidogenesis, acetogenesis and methanogenesis. Fermentative bacteria are responsible for the first stage of anaerobic digestion - hydrolysis and acidogenesis. In this step the complex organic matter like proteins, carbohydrates, lipids etc. were converted into amino acids, sugars, fatty acids, alcohols and intermediate products like propionate, butyrate etc. Hydrogen producing acetogenic bacteria and homoacetogenes are responsible for the next stage of acetogenesis wherein the products of the previous stage are 
converted into acetate, hydrogen and carbon dioxide. Methanogens viz. acetotrophic methanogens and hydrogenotropic methanogens are responsible for the final stage of anaerobic digestion to yield methane and carbon dioxide

\section{Batch study for biogas production}

To study the biomethanation characteristics of the banana wastes, a lab-scale batch digestion experiment was carried out. Anaerobic digestion of banana wastes samples were done in 2 liters amber colored glass bottles. 1.5 liters of banana wastes were taken in each digester. The bottles were covered using rubber cork so that it will be air tight. One glass tube is taken through the stopper and it acts as an outlet for the biogas. To the glass tube a $40 \mathrm{~cm}$ long rubber tube with a pinch cock was connected. In one set of batch experimental setup banana stem wastes were taken whereas mashed peel and mashed peduncle were taken in another set of batch digestion setup. Three replications were made for the study. The batch digestion setup is shown in figure 2 . The following treatment combinations were used for the study.

Banana pseudo stem waste (treatment combinations); each 3 replications

$\mathrm{T}_{1}$ - Banana stem waste $(100 \%)$

$\mathrm{T}_{2}$ - Banana stem waste + Cow dung $(50 \%+$ $50 \%$ )

$\mathrm{T}_{3}$ - Banana stem waste + Cow dung $(75 \%+$ $25 \%$ )

$\mathrm{T}_{4}$ - Banana stem waste + Cow dung $(25 \%+$ $75 \%$ )

\section{Banana peel and peduncle wastes (treatment combinations); each 3 replications}

$\mathrm{T}_{5}$ - Banana mashed peduncle $(100 \%)$

$\mathrm{T}_{6}$ - Banana mashed peel (100\%)
$\mathrm{T}_{7}$ - Banana mashed peduncle + Cow dung $(75 \%+25 \%)$

$\mathrm{T}_{8}-$ Banana mashed peel + Cow dung $(75 \%+$ $25 \%$ )

\section{Measurement of gas production}

The amount of gas produced was measured daily by using water displacement method and expressed in litres $(l)$. Under anaerobic condition, the gas was produced in the bottles within two or three days. The volume of biogas collected daily were added up for seven days and designated as weekly biogas production.

The weekly biogas production for seven weeks were added up and designated as total biogas production and expressed in litres $(l)$. The period of retention was counted from the date of loading (bottle) with feedstock till the cease of gas production. It is expressed in days. Ratio of total biogas production to retention time is designated as average biogas production and expressed as litres per day (l/day). The day at which the maximum biogas production was recorded was designated as occurrence of maximum biogas production and expressed in litres and days. Weekly biogas production were added up sequentially from first to last week which gave the cumulative biogas production and the volume was expressed in litres.

\section{Methane content of gas}

The methane content of the biogas produced was determined by saccharometer experiment as suggested by Ellegard and Egneus (1986). A $5 \mathrm{ml}$ saccharometer was used for this purpose. A solution of distilled water with $10 \% \mathrm{KOH} / \mathrm{NaOH}$ is taken in saccharometer fully filled. A syringe with gas filled of known volume is injected into the solution. $\mathrm{CO}_{2}$ gets dissolved in the solution and undissolved $\mathrm{CH}_{4}$ captures a space in the meter. 
Methane content $(\%)=\frac{V_{1}}{V_{2}}$

Where,

$\mathrm{V}_{1}=$ Volume of undissolved gas, $\mathrm{ml}$

$\mathrm{V}_{2}=$ Volume of gas injected, $\mathrm{ml}$

\section{Results and Discussion}

The physico-chemical characteristics namely TS, VS, TKN, TOC, Fixed carbon and Ash content were analyzed and presented in table 1 . Total Solids (TS) of the banana peel was about $19 \%$ which was higher than the value reported by Debabandhya et al., (2010) of about $16.5 \%$. TS of banana wastes varied between 14 to $19 \%$ which is higher than the optimum value of TS (10\%) for biogas production. Hence the banana wastes were mixed in the ratio of 1:1 with water as in the case of using cow dung as feedstock (TS of cow dung is 20\%). Moisture content of banana wastes were in the range of 81 to $86 \%$ which is more or less similar to the optimum value for anaerobic digestion $(>80 \%)$.

VS of the banana peel was about $77.6 \%$ (of TS) i.e. $14.63 \%$ which was lower when compared to the value reported by Tumutegyereize et al., (2011) of about 87\% (of TS) i.e. $15.66 \%$. Volatile Solids (VS) of banana pseudo stem and fruit bunch stem were about $75.8 \%$ (of TS) i.e. $11.37 \%$ and $72.1 \%$ (of TS) i.e. $10.1 \%$ respectively. These values were high when compared to the value reported by Nurhayati Abdullah et al., (2014) of about $88.8 \%$ (of TS) i.e. $11 \%$ and $79.1 \%$ (of TS) i.e. $9.8 \%$ respectively.

The ash content of banana pseudo stem and fruit bunch stem was about $2.4 \%$ and $2.8 \%$ respectively. These values were low when compared to the value reported by Bilba et al., (2007) of about $8.6 \%$ and $20.6 \%$ respectively. The fixed carbon content of banana pseudo stem and fruit bunch stem was about $1.2 \%$ and $0.9 \%$ respectively.

These values were high when compared to the value reported by Nurhayati Abdullah et al., (2014) of about $0.2 \%$ and $0.3 \%$ respectively. Since the ash content and fixed carbon values were very less (i.e. < $2 \%$ ), it proves that banana wastes are not feasible for energy recovery through thermo-chemical conversion route.

The Total Kjeldahl Nitrogen (TKN) was found to vary in the range of 33 to $34.2 \mathrm{mg} / \mathrm{l}$ and the Total Organic Carbon (TOC) was found to vary in the range of 941.5 to 958 $\mathrm{mg} / \mathrm{l}$. The C: $\mathrm{N}$ ratio was found to vary in the range of 27.53 to 29.03 . The range falls in the optimum $\mathrm{C}$ : $\mathrm{N}$ ratio of 25 to 30 for biomethanation reported by Bouallagui et al., (2003).

Fig.1 Samples of banana wastes - (a) banana peel (b) pseudo stem (c) mashed peel

(d) mashed peduncle

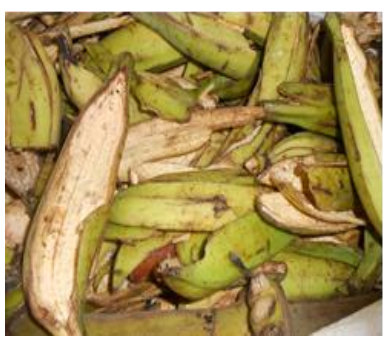

(a)

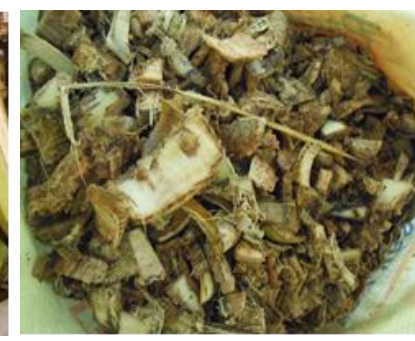

(b)

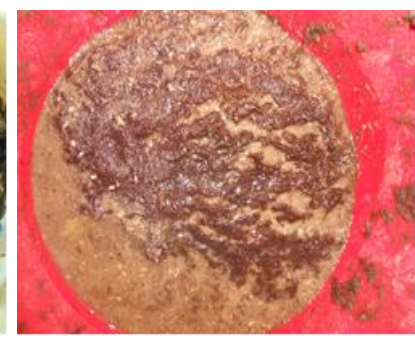

(c)

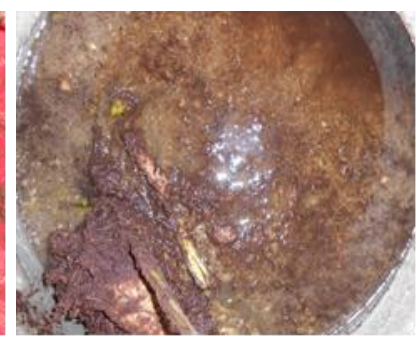

(d) 
Fig.2 Batch anaerobic digestion experimental setup

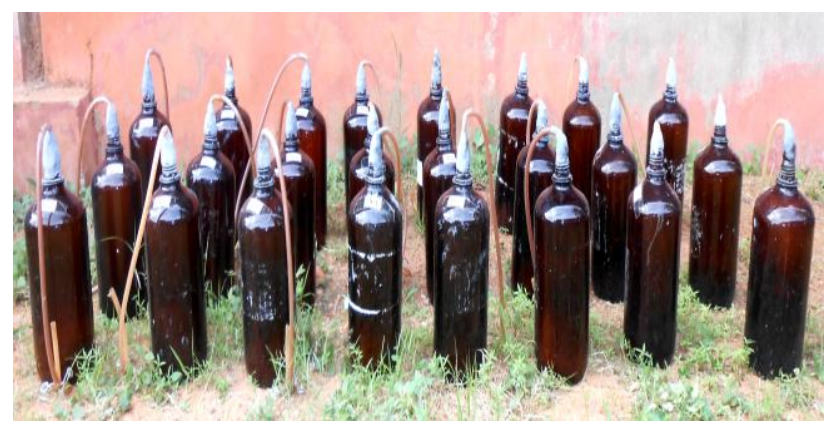

Fig.3 Daily biogas production of treatments in batch study

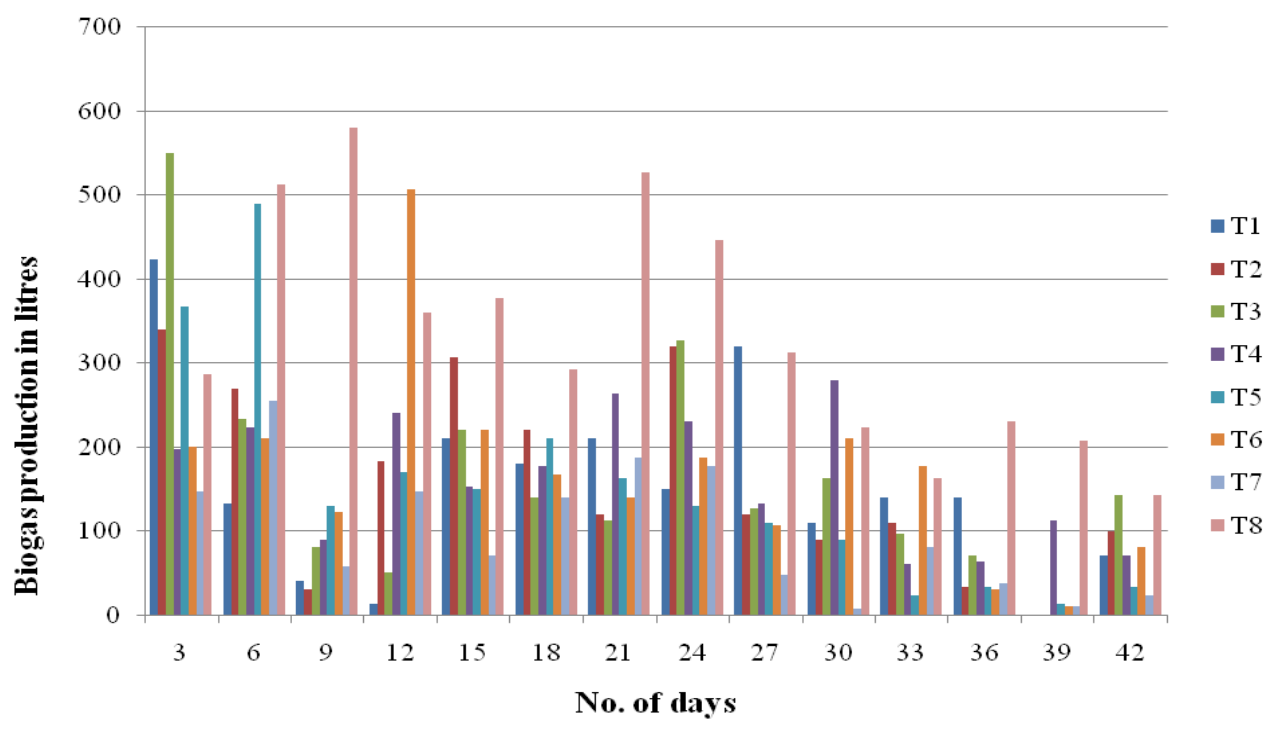

Fig.4 Weekly biogas production of treatments of batch study

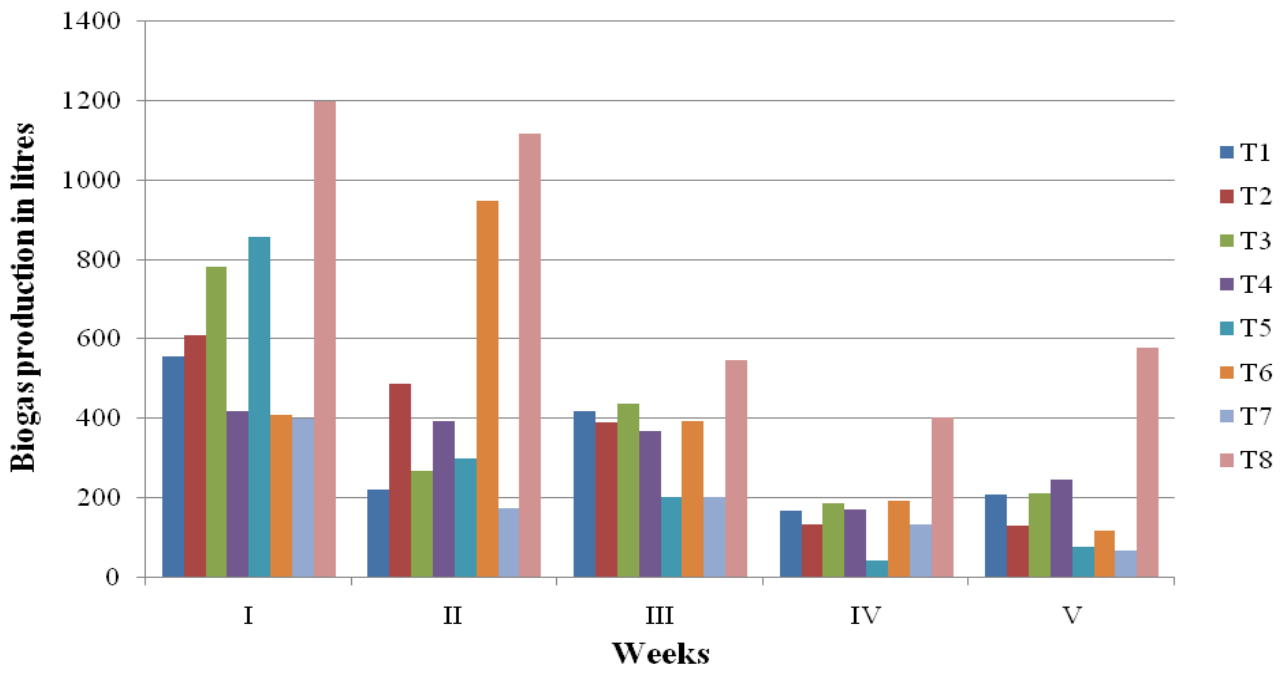


Fig.5 Average methane content of treatments in batch study

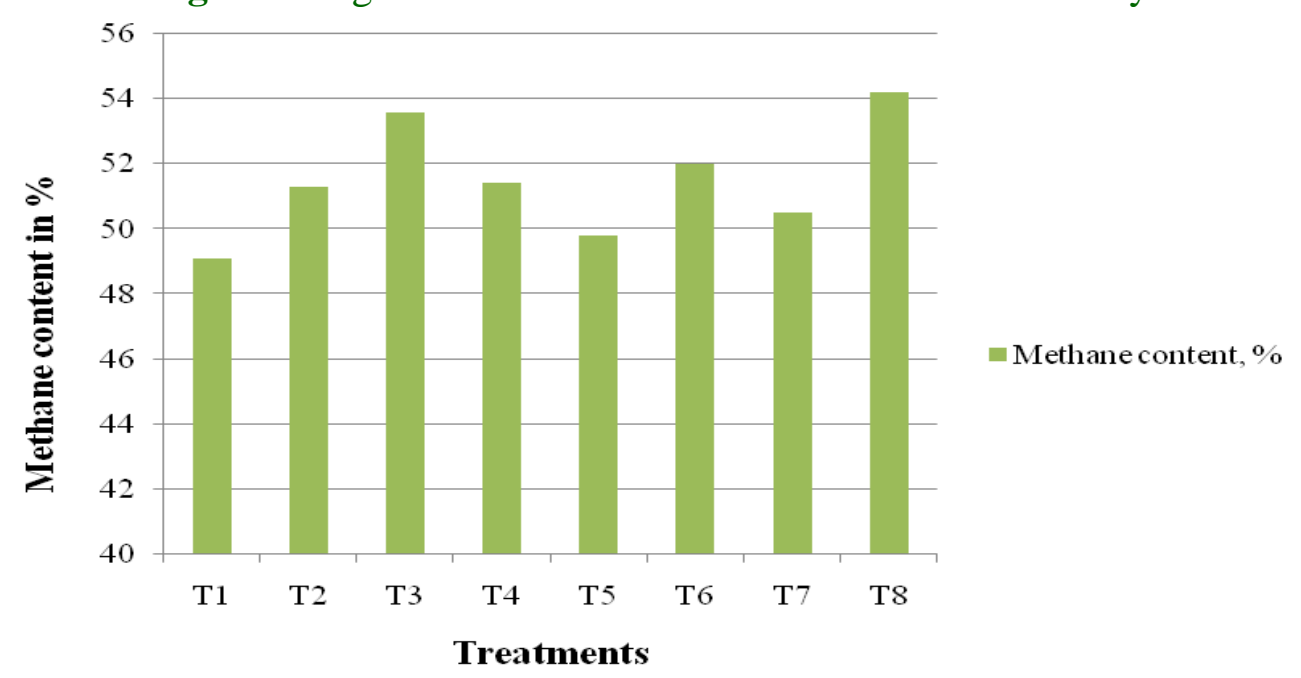

Table.1 Physico-chemical characteristics of banana wastes

\begin{tabular}{|c|c|c|c|c|}
\hline \multirow{2}{*}{ Sl. No } & Parameters & \multicolumn{3}{|c|}{ Values } \\
\cline { 3 - 5 } & & Peel & $\begin{array}{c}\text { Pseudo } \\
\text { stem }\end{array}$ & $\begin{array}{c}\text { Fruit } \\
\text { bunch stem }\end{array}$ \\
\hline 1. & Total Solids (TS), \% & 19 & 15 & 14 \\
2. & Moisture Content, \% & 81 & 85 & 86 \\
3. & Volatile Solids (VS), \% & 14.63 & 11.37 & 10.1 \\
4. & Ash content, \% & 2.9 & 2.4 & 2.8 \\
5. & Fixed Carbon, \% & 1.4 & 1.2 & 0.9 \\
6. & Total Kjeldahl Nitrogen (TKN), mg/l & 33 & 34.2 & 33.65 \\
7. & Total Organic Carbon (TOC), mg/l & 958 & 941.5 & 952 \\
8. & C $:$ N Ratio & 29.03 & 27.53 & 28.29 \\
\hline
\end{tabular}

Table. 2 Weekly biogas production in 8 treatments of batch study

\begin{tabular}{|c|c|c|c|c|c|c|c|c|}
\hline \multirow{2}{*}{ Weeks } & \multicolumn{8}{|c|}{ Biogas Production, litres } \\
\cline { 2 - 9 } & $\mathbf{T}_{\mathbf{1}}$ & $\mathbf{T}_{\mathbf{2}}$ & $\mathbf{T}_{\mathbf{3}}$ & $\mathbf{T}_{\mathbf{4}}$ & $\mathbf{T}_{\mathbf{5}}$ & $\mathbf{T}_{\mathbf{6}}$ & $\mathbf{T}_{\mathbf{7}}$ & $\mathbf{T}_{\mathbf{8}}$ \\
\hline I & 0.56 & 0.61 & 0.78 & 0.42 & 0.86 & 0.41 & 0.40 & 1.2 \\
II & 0.22 & 0.49 & 0.27 & 0.39 & 0.3 & 0.95 & 0.17 & 1.12 \\
III & 0.42 & 0.39 & 0.44 & 0.37 & 0.20 & 0.39 & 0.20 & 0.55 \\
IV & 0.17 & 0.13 & 0.19 & 0.17 & 0.043 & 0.19 & 0.13 & 0.4 \\
V & 0.21 & 0.13 & 0.21 & 0.25 & 0.08 & 0.12 & 0.07 & 0.58 \\
\hline
\end{tabular}

Table.3 Methane content of biogas in 8 treatments of batch study

\begin{tabular}{|c|c|c|c|c|c|c|c|c|}
\hline \multirow{2}{*}{ Weeks } & \multicolumn{7}{|c|}{ Methane Content, \% } \\
\cline { 2 - 8 } & $\mathbf{T}_{\mathbf{1}}$ & $\mathbf{T}_{\mathbf{2}}$ & $\mathbf{T}_{\mathbf{3}}$ & $\mathbf{T}_{\mathbf{4}}$ & $\mathbf{T}_{\mathbf{5}}$ & $\mathbf{T}_{\mathbf{6}}$ & $\mathbf{T}_{\mathbf{7}}$ & $\mathbf{T}_{\mathbf{8}}$ \\
\hline I & 47 & 52 & 55 & 50 & 54 & 56 & 54 & 52 \\
II & 54 & 49 & 57 & 54 & 52 & 53 & 48 & 55 \\
III & 49 & 55 & 56 & 56 & 49 & 54 & 55 & 56 \\
IV & 47.5 & 48.5 & 46 & 46 & 45 & 46 & 47 & 55 \\
V & 48 & 52 & 54 & 51 & 49 & 51 & 48.5 & 53 \\
\hline
\end{tabular}




\section{Batch anaerobic digestion of banana wastes}

To study the biomethanation characteristics of banana wastes in lab-scale, a batch experiment was conducted. The collected banana wastes were fed into the batch digester. The batch study was continued till the biogas production ceased. The daily biogas production was observed. The weekly biogas production over three replications for all treatments was presented in table 2. Also the methane content of biogas produced in 8 treatments of batch study over weeks was presented in table 3 .

The daily biogas production, biogas production over the weeks of batch study and the average methane content of biogas in the treatments were depicted in figures 3-5 respectively. The maximum biogas production of $3.85 l$ was obtained in the treatment $\mathrm{T}_{8}$, whereas the minimum biogas production of $0.98 l$ was obtained in the treatment $\mathrm{T}_{7}$. Since the treatment combination of $75 \%$ mashed banana peel and $25 \%$ cow dung proved higher biogas production compared to other treatments, it was selected as the optimum treatment combination for field study. The specific biogas production ( $l / \mathrm{kg}$ of feed) was found to be around 0.35 $l / \mathrm{kg} /$ day. The methane content of biogas produced in the treatment $T_{8}$ was found to be comparatively higher with an average of $54.2 \%$.

To summarize and conclude, from the characterization study it was found that the total solids of the banana wastes (viz. peel, peduncle and stem) varied between 14 to $19 \%$. The moisture content of banana wastes were in the range of 81 to $86 \%$. Volatile solids of banana wastes with respect to TS were in the range of 10.1 to $14.63 \%$. The ash content and fixed carbon values of banana wastes were 2.4 to $2.9 \%$ and 0.9 to $1.4 \%$ respectively. The Total Kjeldahl Nitrogen and
Total Organic Carbon were found to vary in the range of 33 to $34.2 \mathrm{mg} / \mathrm{l}$ and 941.5 to 958 $\mathrm{mg} / \mathrm{l}$ respectively. The $\mathrm{C}: \mathrm{N}$ ratio of banana wastes falls in the range of 27.53 to 29.03 . From the batch anaerobic digestion experiment conducted to study the biogas production potential of banana wastes, it was found that the gas production started from the third day of feeding the samples into the bottles and was found to gradually increase over time. The specific biogas production of banana wastes $(l / \mathrm{kg}$ of feed) obtained from batch study was found to be around 0.35 $l / \mathrm{kg} / \mathrm{day}$. The maximum biogas production was obtained in the treatment combination of $75 \%$ mashed banana peel with $25 \%$ of cow dung which was about 3.85 litres with comparatively higher methane content of about $54 \%$.

\section{Acknowledgment}

We would like to solicit our earnest gratitude to the Ministry of New and Renewable Energy (MNRE), Government of India for providing the funds necessary to carry out the study.

\section{References}

APHA. 1989. Standard methods for the examination of water and wastewater. American Public Health Association, Washington.

ASTM D3174-12. 2012. Standard Test Method for Ash in the Analysis Sample of Coal and Coke from Coal, ASTM International, West Conshohocken, PA.

ASTM D3175-11. 2011. Standard Test Method for Volatile Matter in the Analysis Sample of Coal and Coke, ASTM International, West Conshohocken, PA.

Bilba, K., Arsene, M.A. and Ouensanga, A. 2007. Study of banana and coconut fibers botanical composition, thermal 
degradation and textural observations. Bioresource Technology. 98 (1): 58-68.

Bouallagui, H., Cheikh, R.B., Marouani, L. and Hamdi, M. 2003. Mesophilic biogas production from fruit and vegetable waste in a tubular digester. Bioresource Technology. 86: 85-85.

Browning, B.L. 1967. Methods of wood chemistry. Vol. II. Ed., Wiley, New York, 1967. 498.

Debabandya Mohapatra, Sabyasachi Mishra and Namrata Sutar. 2010. Banana and its by-product utilization: an overview. Journal of Scientific and Industrial Research. 69: 323-329.

Ellegard, A., and Egneus, H. 1986. A simple, rapid and accurate method for determination of carbon dioxide in biogas. 494-497. M. M. El-Halwagi eds. Biogas technology, transfer and diffusion. Cairo: Elsevier Applied Science Publishers Ltd

National Horticulture Board report on Banana. Web access:
http://nhb.gov.in/report_files/banana/B ANANA.htm.

Nelson, D. W., and L. E. Somners. 1996. Total carbon, total organic carbon, and organic matter. In Methods of soil analysis, part 3: Chemical methods, ed D. L. Sparks, 961-1010. Madison, Wisc: Soil Science Society of America.

Nurhayati Abdullah, Fauziah Sulaiman, Muhamad Azman Miskam and Rahmad Mohd Taib. 2014. Characterization of Banana (Musa spp.) Pseudo-Stem and Fruit-Bunch-Stem as a Potential Renewable Energy Resource. International Journal of Biological, Veterinary, Agricultural and Food Engineering. 8(8)

Tumutegyereize, P., Muranga, F.I., Kawongolo, J. and Nabugoomu, F. 2011. Optimization of biogas production from banana peels: Effect of particle size on methane yield. African Journal of Biotechnology. 10(79): 18243-18251.

\section{How to cite this article:}

Divyabharathi, R., R. Angeeswaran, K. Jagadeeshkumar and Pugalendhi, S. 2017. Characterization and Batch Anaerobic Digestion Study of Banana Wastes. Int.J.Curr.Microbiol.App.Sci. 6(7): 2307-2315. doi: https://doi.org/10.20546/ijcmas.2017.607.331 